\title{
КОНТРОЛЬНО-ОЦІНЮВАЛЬНА ДІЯЛЬНІСТЬ МОЛОДШИХ ШКОЛЯРІВ У КОНТЕКСТІ НОВОЇ УКРАЇНСЬКОЇ ШКОЛИ
}

\author{
Гарачук Т. В. \\ кандидат педагогічних наук, \\ дочент кафедри дошкільної і початкової освіти \\ КЗВО «Одеська академія неперервної освіти Одеської обласної ради» \\ пл. Михайлівська, 17, Одеса, Украӥна \\ orcid.org/0000-0002-2019-8515 \\ tanya.garachukk@gmail.com
}

\begin{abstract}
Ключові слова: оцінювання, формувальне очінювання, учень початкової школи, компетентність, контроль, алгоритм оцінювання.
\end{abstract}

У статті на основі аналізу довідкових, психолого-педагогічних і наукових джерел та емпіричного аналізу основних понять теми розглянуто контрольно-оцінювальну діяльність учнів в умовах Нової української школи. Проаналізовано форми оцінювання навчальних досягнень школярів (прогностичне, діагностичне, формувальне, підсумкове). Подано характеристику кожної форми оцінювання та наведено конкретні приклади. Зазначено, що формувальне оцінювання $\epsilon$ інновацією Нової української школи та вивчено його понятійно-змістовий аспект. Охарактеризовано формувальне оцінювання як форму оцінювання, яка заснована на поставлених цілях, ціннісне для вчителів та учнів, забезпечує тісний зв'язок із майбутнім та $\epsilon$ виключно позитивним. Акцентовано увагу на цілях та завданнях формувального оцінювання. Виокремлено особливості здійснення формувального оцінювання в освітньому процесі початкової школи. У контексті дослідження розглянуто форми формувального оцінювання (взаємодія «ученьучитель», взаємодія «учень-учитель-батьки», самооцінювання власної діяльності, оцінювання 3 боку однолітків, оцінювання 3 боку групи). До кожної форми формувального оцінювання підібрано дієві приклади. Розтлумачено та проаналізовано алгоритм діяльності учителя під час здійснення формувального оцінювання (формулювання об'єктивних і зрозумілих для учнів навчальних цілей; ознайомлення учнів із критеріями оцінювання; забезпечення активної участі учнів у процесі оцінювання; забезпечення можливості й уміння учнів аналізувати власну діяльність; коригування спільно з учнями підходів до навчання 3 урахуванням результатів оцінювання). У такому контексті показано шляхи здійснення формувального оцінювання в освітньому процесі Нової української школи. Спираючись на предмет дослідження, в КЗВО «Одеська академія неперервної освіти Одеської обласної ради» було проведено опитування педагогів для з'ясування ролі та місця контрольно-оцінювальної діяльності учнів в умовах Нової української школи. Загалом, учителі орієнтуються в нормативно-правовому забезпеченні контрольнооцінювальної діяльності школярів, оперують основними поняттями, застосовують інновації, впроваджують цифрові інструменти здійснення формувального оцінювання, однак деякі аспекти ще потребують додаткового роз'яснення та уточнення. 


\title{
MONITORING AND EVALUATION ACTIVITY OF PRIMARY SCHOOL STUDENTS IN THE CONTEXT OF THE NEW UKRAINIAN SCHOOL
}

\author{
Harachuk T. V. \\ Doctor of Philosophy, \\ Assistant Professor at Preschool and Primary Education Department \\ Odessa Regional Academy of In-service Education \\ Mykhailivska square, 17, Odessa, Ukraine \\ orcid.org/0000-0002-2019-8515 \\ tanya.garachukk@gmail.com
}

Key words: assessment, formative assessment, primary school student, competence,

The article is based on the analysis of reference, psychological, pedagogical and scientific sources and empirical analysis of the basic concepts of the topic are considered the control and evaluation activities of students of the New control, algorithm of assessment.

Ukrainian School. Forms of assessment of students' academic achievements (prognostic, diagnostic, formative, final) are analyzed. The characteristics of each form of assessment and specific examples are given. It is noted that formative assessment is an innovation of the New Ukrainian School and its conceptual and semantic aspect is studied. Formative assessment is characterized as a form of assessment that is based on goals, valuable for teachers and students, provides a close connection with the future and is extremely positive. Attention focused on the goals and objectives of formative assessment. Peculiarities of formative assessment in the educational process of primary school are singled out. In the context of the research, the forms of formative assessment are considered (interaction "student-teacher", interaction "student-teacher-parents", self-assessment, peer assessment, group assessment). Effective examples are selected for each form of formative assessment. The algorithm of the teacher's activity during the formative assessment is explained and analyzed (formulation of objective and understandable for students learning goals; acquaintance of students with assessment criteria; ensuring active participation of students in the assessment process; providing students with the opportunity and ability to analyze own activities; adjusting approaches to learning together with students taking into account the results of assessment). In this context, the ways of carrying out formative assessment in the educational process of the New Ukrainian School are shown. Based on the subject of the research, a survey of teachers was conducted in the Odessa Regional Academy of In-Service Education for finding out the role and place of control and evaluation activities of students in the New Ukrainian School. In general, teachers are oriented in the legal support of control and evaluation activities of students, operate with basic concepts, apply innovations, implement digital tools for formative assessment, but some aspects still need further clarification and explanation.

Постановка проблеми. Стрімкий розвиток світового суспільства, зміна парадигми мислення, реформування системи освіти України, трансформація сучасного освітнього процесу, перехід від знаннєвої до діяльнісної моделі навчання - все це зумовило суттєві зміни в контрольно-оцінювальній діяльності школярів. Нині контроль та оцінювання навчальних досягнень учнів полягає не тільки у здійсненні етапу перевірки виконання завдання та оцінювання знань школярів на уроці. Цей процес взаємопов'язаний із розвитком соці- альних, особистісних та інтелектуальних якостей дитини, iii свідомим ставленням до навчання та взаємодії із суспільством загалом. Однак у минулому тільки успішність у школі, оцінка $з$ поведінки чи зразкова характеристика дуже часто визначала долю людини, iіi професію та майбутнє життя.

Розвиток сучасного освітнього процесу Нової української школи зумовив переорієнтацію на компетентнісне навчання та спонукав до перегляду основних підходів до оцінювання навчальних досягнень учнів. Контрольно-оцінювальна 
діяльність у такому контексті є однією 3 найважливіших, а 3 іншого боку, одним 3 найскладніших явищ, адже оцінювання завжди виступало одним із найдієвіших інструментів педагога.

Багато проблем, пов'язаних із здійсненням оцінювання, виникало через незрозуміло та нечітко поставлені цілі, акцентування на недоліках та слабких сторонах дитини, неправильно сформульовані вимоги до результатів навчання, впровадження необ'єктивних інструментів оцінювання, ігнорування особистісної сфери розвитку дитини, iii здатностей та типу сприймання інформації. Як результат, діти набувають низку комплексів, зневірюються у навчанні, втрачають бажання здобувати результати, бояться помилитися та здатися некомпетентними, не вірять у свої можливості та здібності. Тому нові підходи до оцінювання і передбачають оцінювати не теоретичні знання дітей, а їхню соціально-психологічну компетентність, надавати можливість демонструвати власні досягнення різними способами, формувати та розвивати впевненість у власних силах та позитивне ставлення до самого себе тощо. Отже, оцінювання у сучасній школі перестає виступати як інструмент фіксації результатів успішності учнів, а постає засобом навчання.

Проблема здійснення контрольно-оцінювальної діяльності школярів досить грунтовно висвітлювалась у наукових дослідженнях, але виявилося, що увага приділялася лише окремим іiї аспектам. Так, досліджувався ретроспективний аналіз стану проблеми контролю й оцінювання успішності учнів (О. Савченко), проблема вимірювання освітніх результатів початкової освіти 3 досвіду міжнародних порівняльних досліджень (Н. Бібік), питання контролю та оцінювання навчальних досягнень учнів з математики (О. Онопрієнко), оцінювання учнів 3 громадянської освіти в контексті компетентнісного підходу (О. Пометун, T. Ремех), особливості конструювання, методика контролю та особливості оцінювання державної підсумкової атестації (О. Вашуленко, О. Онопрієнко, К. Пономарьова) тощо.

Проблему організації та здійснення формувального оцінювання студіювали О. Барановська, М. Барна, Б. Бович, І. Булах, Н. Буханевич, В. Вебер, Дж. Вілмут, О. Гезей, Л. Кабан, I. Коберник, Н. Кравець, Н. Морзе, М. Мруга, Д. Ротфорт, Н. Софій, О. Фідкевич, І. Фішман, Р. Шакіров, О. Щербак та ін. Окремі аспекти реалізації формувального оцінювання досліджували I. Баландіна, Т. Воронцова, О. Гончарова, Н. Дементієвська, I. Ільїна, О. Локшина, В. Садкіна, О. Пономаренко, Г. Цукерман та ін.

Водночас питання організаціїтаздійснення контрольно-оцінювальної діяльності учнів на сучасному етапі залишається не досить дослідженим.
Мета статті - висвітлити суть та специфіку здійснення контрольно-оцінювальної діяльності учнів в умовах Нової української школи.

Виклад основного матеріалу дослідження. Контрольно-оцінювальна діяльність - важливий елемент освітнього процесу, який залучає та привертає увагу учнів, батьків, керівництва, громадськості. Впроваджуючи контроль та оцінювання, педагог визначає ступінь особистісноївідповідальності кожного за якість освітнього процесу, адже оцінка може як заохочувати та мотивувати, так i пригнічувати та гальмувати розвиток школярів.

Згідно 3 особливостями контрольно-оцінювальної діяльності Фінляндії, оцінювання не виступає основною діяльністю педагога у школі, учнів не порівнюють один з одним, у країні немає «національного» оцінювання, керівництво не контролює та не оцінює вчителів, а вчителі, своєю чергою, не оцінюють один одного, не існує перевірки методичного забезпечення, вчителю надається повна академічна свобода, а оцінювання не сфокусоване на індивідуально-психологічних властивостях дитини тощо [12].

Своєю чергою реформа Нової української школи внесла суттєві корективи у процес контролю та оцінювання учнів. Натепер освітній процес зосереджено на реальних досягненнях школярів, оцінка існує для аналізу індивідуальних досягнень та планування особистісного зростання. Отже, оцінка - це доцільна та об'єктивна рекомендація до дії, а не осуд чи присуд. Згідно з нормативними документами, вимірювання навчальних досягнень здобувачів освіти повинне здійснюватися шляхом формувального оцінювання, яке допомагає відстежувати індивідуальний поступ дитини, процес опанування навчального досвіду та спрямоване на підтримку в учнях упевненості та мотивації до пізнання $[5 ; 6]$. Сучасна концепція контролю та оцінювання визначає, що $18 \%$ оцінювання реалізує вчитель, $32 \%$ відбувається через оцінювання 3 боку групи чи взаємооцінювання і $50 \%$ - це самооцінювання дитини власної навчальної діяльності.

Актуальною $\epsilon$ точка зору фінських дослідників-практиків (А. Хурінайнен-Косунен, Р. Палмквіст), які виокремлюють такі форми оцінювання: прогностичне, діагностичне, формувальне та підсумкове [12]. Розглянемо їх детальніше.

У контексті НУШ прогностичне оцінювання часто трактується як попереджувальне оцінювання та застосовується для формулювання нових цілей навчання; роздуми про перебіг майбутнього освітнього процесу; міркування про допомогу, якої потребує чи буде потребувати молодший школяр. Така форма оцінювання допоможе вибрати відповідний темп засвоєння навчального матеріалу, прогнозує вибір оптимальних методів, прийомів 
та засобів пізнавальної і практичної діяльності учнів, допомагає визначити індивідуальні особливості школярів в опануванні змісту й дібрати відповідний темп засвоєння та рівень складності навчального матеріалу. Дієвими методиками для здійснення прогностичного оцінювання $є$ «Оцінювальний лист», «Чарівна лінійка», «Знаю-відчуваю труднощі-не знаю», «Де я $є ? »$ тощо. Наприклад, подумай: Що із запропонованого ти можеш виконати одразу? Для виконання яких завдань ти потребуєш допомоги? Висновимо, що такі методики дозволяють учням початкової школи оцінити власні можливості та спроможність до розв'язання навчальних завдань.

Д. Ротфорт, О. Гезей в основних функціях контролю та оцінювання навчальних досягнень школярів визначають діагностичну функцію, яка, на наш погляд, повністю збігається із суттю діагностичного оцінювання. На їхню думку, діагностична функція полягає у виявленні й діагностуванні прогалин та помилок у знаннях і вміннях учнів відповідно до сформульованої мети та цілей навчання, вивчення причин їх виникнення, вчасної корекції та усунення [11, с. 13-14]. Щодо шляхів здійснення діагностичної функції, то було виокремлено: використання різних форм контролю; постійне заохочення старанності дітей, формуючи у них упевненість та віру у власні сили; зміна стилю викладання; систематична діагностична інформація про рівень успішності дитини тощо [11, с. 13-14].

На нашу думку, діагностичне оцінювання - це оцінювання для визначення можливостей та труднощів учня у процесі навчання і надання вчасної дієвої допомоги на наступних етапах. Таке оцінювання здійснюється за допомогою різних методик, тесту, бесіди, графічних завдань, читання за зразком, шляхом виконання спеціальних робіт тощо. Наголосимо, що така форма оцінювання дозволяє визначити рівень сформованості та розвитку відповідних компетентностей, проводиться перед вивченням теми, розділу чи модулю та допомагає вчителю встановити відхилення між поточними та бажаними результатами.

Підсумкове оцінювання, як зазначено у Методичних рекомендаціях щодо оцінювання навчальних досягнень учнів другого класу, здійснюється упродовж навчального року за результатами опанування відповідних тем, розділів та може визначати освітні індивідуальні завдання школярів на наступні етапи навчання [6]. О. Пометун, Т. Ремех наголошують, що підсумкове (сумативне, завершальне) оцінювання все ще $\epsilon$ найбільш поширеним у вітчизняному освітньому просторі та «спрямоване на перевірку того, що опанували й здобули учні, воно оцінює результат (досягнення певного рівня) після завершення освітнього процесу (його етапу) ... має на меті оцінити якість відповідно до державного освітнього стандарту» [10, с. 88]. Таке оцінювання здійснюється за допомогою діагностичних та перевірних робіт, компетентнісних тестів, тестових завдань, практичної роботи, усного опитування. Отже, підсумкове оцінювання виступає як кінцеве, остаточне оцінювання рівня опанування ключовими та предметними компетентностями, стосується тільки минулого, вимагає чітких розроблених критеріїв, показує недоліки та якість навчання, є доказовим та вимагає засобів вимірювання.

Однак інновацією Нової української школи у контрольно-оцінювальній діяльності учнів, безперечно, $є$ формувальне оцінювання.

О. Локшина зазначає, що у вітчизняному освітньому просторі немає єдиного універсального перекладу 3 англійської мови словосполучення "formative assessment". Нині можна зустріти такі варіанти перекладу, як «описове», «формативне», «формуюче», «формаційне», «формувальне», «розвивальне», «заохочуюче», «нетрадиційне» тощо. Науковець, звертаючи увагу на змістове наповнення поняття «оцінювання, що сприяє формуванню й розвитку особистості учня», а також на традиції української мови та іії лексико-граматичні вимоги, наполягає на використанні терміна «формувальне оцінювання» [4].

У цьому контексті заслуговують на увагу результати дослідження I. Коберник, яка зазначила, що в англійській мові $є$ два слова, які перекладаються як оцінювання, - "assessment" та "evaluation". Різні науковці та дослідники наділяють ці поняття різною суттю та перекладають по-різному, у результаті заплутуючи та ускладнюючи увагу педагогів. Дослідниця проаналізувала західні іншомовні джерела та висновила, що в країнах, які впроваджують компетентнісний підхід у навчанні та формувальне оцінювання, ці дві дефініції розмежовано чітко і доступно. Так, "assessment" вживається у значенні «формувальне оцінювання», а "evaluation" має основні риси підсумкового оцінювання [3].

С. Покрова тлумачить формувальне оцінювання як «судження про рівень навчальних досягнень школярів» [9, с. 7]. Н. Морзе, О. Барна, В. Вембер розглядаюіть, з одного боку, як зворотний зв'язок, який дозволяє школярам збагнути, яких заходів варто вжити, щоб покращити особистісні результати, а з іншого - забезпечується тісний зв'язок з індивідуальною траєкторією розвитку дитини, розвитком їі компетентностей [7]. Л. Кабан як «цілеспрямований неперервний процес спостереження за навчанням учнів; воно $\epsilon$ необхідною умовою інтерактивного навчання, у процесі якого формується культура спільного обговорення у класі, розвиваються навички кри- 
тичного і творчого мислення, а також формується середовище, що заохочує учнів запитувати» [2].

Отож, зазначимо, що наявні різноманітні тлумачення поняття «формувальне оцінювання», які інколи $є$ тотожними та взаємодоповнюючими, а інколи суперечать один одному. На нашу думку, формувальне оцінювання - це форма оцінювання, яка заснована на поставлених цілях, ціннісне для вчителів та учнів, забезпечує тісний зв'язок із майбутнім та $є$ виключно позитивним.

У пораднику для вчителів Нової української школи зазначено, що шляхом формувального оцінювання відстежується індивідуальний розвиток школяра та процес оволодіння ним досвідом навчальної діяльності. Така форма оцінювання спрямована на досягнення таких завдань:

- заохочувати бажання школярів отримувати максимально можливі результати;

- уміння будувати індивідуальну траєкторію розвитку молодших школярів;

- своєчасно та систематично діагностувати проблеми та попереджати їх нашарування;

- формувати актуальні якості та властивості особистості (відсутність страху, уміння доводити свою думку, почуття приналежності до спільноти, упевненість у власній спроможності тощо);

- формувати та розвивати навички оцінювання досягнень учнів на кожному етапі освітнього процесу [9, с. 94].

Дж. Вілмут через цілі оцінювання підходить до форм оцінювання. Так, метою формувального оцінювання, на думку науковця, є підтримання школярів в освітньому процесі. Задля цього оцінювання повинне: проєктувати наступні кроки у навчанні; вказувати сильні сторони та майбутні досягнення учнів; виокремлювати сфери, які потребують розвитку, коригування чи удосконалення; постійно мотивувати дітей через визнання їхніх перемог, здобутків та особистісного прогресу [1, с. 5]. Зазначено, що формувальне оцінювання потребує зворотного зв'язку як діалогу між учителем-учнями, учителем-батьками, учителем-учнями-батьками.

Завдяки роботам [3; 12] було виокремлено основні особливості формувального оцінювання: оцінює процес, а не результат; базується на чітких поставлених цілях; відомості про поступ в освітньому процесі учня описові, якісні; демонструє тісний зв' язок між учасниками освітнього процесу; відбувається у різних формах (діалог); може спиратися на самооцінювання; $є$ індивідуалізованим та ціннісним; може бути доведене; потребує критеріїв та засобів вимірювання; надає зворотний зв'язок; метою $є$ підвищення якості освітнього процесу; часто виступає засобом діагностування тощо.

Варто зазначити, що на початку навчального року школяр за допомогою вчителя має визначити та сформулювати власні цілі навчання, роботи та поведінки, надалі систематично відповідаючи на питання: «Де я зараз?», «Куди я йду?», «Як можу досягти поставленої цілі?», «Що мені вдалося?», «Що я зміг?» тощо.

Отож, на перших батьківських зборах варто провести роз'яснювальну роботу стосовно контрольно-оцінювальної діяльності в Новій українській школі загалом та формувального оцінювання зокрема. Адже перехід до нової суті та форми оцінювання вимагає глибокого розуміння, зміни парадигми, установок та переконань кожного учасника освітнього процесу. Отже, варто роз'яснити суть та основні особливості формувального оцінювання («навчання без оцінок», критерії оцінювання, свідоцтво досягнень, діагностичні роботи), роль учня в оцінюванні власного навчання, роль батьків в оцінюванні навчального поступу власної дитини, специфіку побудови індивідуальної траєкторії розвитку школяра тощо.

А. Хурінайнен-Косунен, Р. Палмквіст виокремлено форми формувального оцінювання:

1. Взаємодія «учень-учитель»:

- розгляд діяльності учня у школі, його кроки та поступ у навчанні;

- учень усно самостійно оцінює себе, а вчитель виражає власну думку;

- виокремлення та формулювання разом навчальних цілей на майбутнє, які згодом доводять до відома батькам.

Наприклад, «Моя ціль ... - як мені це вдалося?», «Я добре працюю самостійно. Моя ціль ...», «Мої джерела радості у школі», «Мої причини занепокоєння у школі», «Опиши ситуації, 3 якими ти добре впорався у школі», «Мої цілі на майбутнє ...», «Чи вдається мені дотримуватися правил? Чи я все ще тренуюся?», «Якщо потрібно попрацювати, то як?» тощо.

2. Взаємодія «учень-учитель-батьки»:

- все концентрується на поступі учня, цілі у навчанні формулюються на перспективу;

- засновано на усному/письмовому самостійному оцінюванні школярів та отриманих результатах;

- спирається на оцінюванні діяльності у школі, яке проводиться разом з батьками;

- доцільно застосувати докази та факти (фото, відео, зразки робіт, вироби, твори тощо).

Наприклад, під час обговорення результатів оцінювання можна ставити такі питання: «Що нині цікавить вашу дитину?», «Як ваша дитина поводиться з однолітками?», «Що засмучує дитину?», «Які очікування у вас від співпраці з учителем?», «Як ви думаєте, чи реалістично ваша дитина оцінює свої навички?», «Чи ваша дитина ходить до школи задоволена?», «Чи досить у вас інформації щодо роботи вашої дитини в школі та її поступу в навчанні?» тощо. 
3. Самооцінювання власної діяльності:

- школяра навчають оцінювати особисту діяльність, як наслідок, формуються та розвиваються навички самооцінювання;

- метою самооцінювання $\epsilon$ виховання впевненого в собі учня, який уміє мислити критично, $є$ об'єктивним та неупередженим, уміє визначати свої сильні сторони, зони покращення та напрями розвитку.

Наприклад, у разі здійснення самооцінювання можна керуватися такими питаннями та твердженнями: «Мене у школі захоплює...», «Мене у школі непокоїть ...», «Чи умію я працювати самостійно?», «Чи я сам дбаю про свою домашню роботу?», «Я пам'ятав про те, що перед тим, як щось сказати, треба підняти руку», «Я давав усім спокійно працювати» тощо.

4. Оцінювання з боку однолітків:

- учні вчаться надавати зворотний зв'язок однокласникам;

- відбувається постійне тренування уміння надавати конструктивний та позитивний зворотний зв'язок згідно зі сформульованими цілями.

Наприклад, оцінювання 3 боку однолітків варто здійснювати, керуючись питаннями чи ситуаціями, як-от: «Чи умію я працювати у парі чи у групі?», «Чи поводжуся я 3 іншими дружньо?», «Подумай про те, як однолітки могли б тобі допомогти, якби у тебе були труднощі?», «Чи знаєш ти, як гратися з іншими дітьми під час перерв без суперечок?». Учні разом читають власні письмові твори та дають конструктивний зворотний зв'язок або учні вивчають вироби 3 мистецтва один одного та надають спрямований зворотний зв'язок щодо виробів інших тощо.

5. Оцінювання з боку групи:

- група вчиться оцінювати власну роботу після закінчення групового завдання (проєкту).

Наприклад, для оцінювання власної діяльності з боку групи можна керуватися такою формою оцінювання, де 1 - згоден; 2 - згоден, але не зовсім; 3 - повністю не згоден: а) Група добре працювала. б) Кожен взяв на себе відповідальність за виконання завдання. в) Ми змогли легко домовитися про свої ролі. г) Вважаємо, що завдання були легкими. г) Вважаємо, що завдання були звичайного рівня складності. д) Вважаємо, що завдання були складними. Питання: «Що було найкращим у цьому методі роботи?», «Подумай, чи можна цей метод роботи покращити. Як?», «Що ти дізнався про цю тему» [12].

Зазначимо, охарактеризовані форми формувального оцінювання $\epsilon$ доцільними, актуальними і вартими до впровадження в освітній процес Нової української школи.

У Методичних рекомендаціях щодо оцінювання навчальних досягнень учнів першого класу подано алгоритм діяльності вчителя під час здійснення формувального оцінювання:

1. Формулювання об'єктивних і зрозумілих для учнів навчальних цілей. Педагог разом 3 учнями формулює доступні та об'єктивні цілі, а потім за допомогоюоцінювання вимірює, яквонидосягнуті.

2. Ознайомлення учнів із критеріями оцінювання. Для кожного виду діяльності педагог розробляє критерії оцінювання, які будуть зрозумілими та сприйнятливими для школярів. Учень повинен знати, що саме буде оцінюватися, для того щоб самостійно чи за допомогою вчителя перевірити досягнення поставлених цілей. Для початку учням варто надавати готові критерії оцінювання, а потім на основі запропонованих школярі можуть разом 3 учителем брати участь у розробці критеріїв оцінювання різних видів навчальної діяльності. Щодо процедури розробки критеріїв оцінювання, то вона може бути така: визначення та формулювання цілей уроку; продукування учнем, згідно з цілями, одного-двох критеріїв; занотовування запропонованих критеріїв; наступний розбір та аналіз поданих критеріїв; розміщення критеріїв за ступенем важливості та об'єктивності; встановлення балів для кожного критерію тощо.

3. Забезпечення активної участі учнів у процесі оцінювання. Запровадження ефективного зворотного зв'язку має стати основним у залученні школярів до здійснення формувального оцінювання. Педагоги повинні наголошувати лише на позитивних аспектах дитини, iї перевагах, успіхах та сильних сторонах і пам'ятати про те, що варто порівнювати дитину з іiі попередніми результатами, однак не порівнювати одну дитину з іншою.

Основною формою обговорення перебігу та результатів навчальної діяльності учня є індивідуальна бесіда, на якій корегуються цілі, визначаються напрями для майбутнього зростання, відзначається індивідуальний поступ у навчанні, обговорюються труднощі чи аспекти самовдосконалення. У такому контексті важливим $\epsilon$ взаємооцінювання як партнерська взаємодія покращення навчальних та особистісних результатів.

4. Забезпечення можливості й уміння учнів аналізувати власну діяльність. Ще 3 першого класу учнів доцільно навчити розглядати та аналізувати власну навчальну діяльність (рефлексувати). Рефлексія - це, з одного боку, здійснення самоаналізу власної діяльності та ії результатів, а 3 іншого - осмислення та усвідомлення інформації. Варто наголосити, що виокремлюють рефлексію настрою та емоційного стану («Що мене розважило?», «Як я почувався на уроці?», «Чи було мені комфортно?»), рефлексію діяльності («Як ти впорався із завданням?», «Чи я працював творчо?», «Хотів би я продовжити роботу?») та рефлексію змісту навчального матеріалу («Що 
змусило мене задуматися?», «До чого б не хотілося повертатися?», «Що я візьму із собою?»). Як результат, у дітей закладається підгрунтя для самоаналізу та самоспостереження, які у майбутньому переходять на рефлексивний рівень.

5. Коригування спільно з учнями підходів до навчання 3 урахуванням результатів оцінювання. Формувальне оцінювання дозволяє педагогам спостерігати за процесом досягнення індивідуальних цілей навчання, їх вчасно коригувати, змінювати, удосконалювати тощо. 3 урахуванням результатів навчання коригуванню підлягає також індивідуальна траєкторія розвитку дитини - особистісний шлях реалізації потенціалу учня, що формується та розвивається з урахуванням можливостей, здібностей, нахилів, уподобань, світогляду, особистісних потреб та власного досвіду [5].

Слід зауважити думку Л. Кабан, яка пропонує власний алгоритм діяльності педагога у застосуванні формувального оцінювання: формулювання об'єктивних і зрозумілих для учнів навчальних цілей; створення ефективного зворотного зв'язку; забезпечення активної участі учнів у процесі пізнання; ознайомлення учнів із критеріями оцінювання; забезпечення можливості й уміння учнів аналізувати власну діяльність (рефлексія); корегування спільно з учнями підходів до навчання з урахуванням результатів оцінювання [2]. Алгоритм $€$ майже тотожним, однак дослідник дещо конкретизувала та уточнила хід діяльності вчителя.

Вважаємо доречним у цьому контексті зазначити шляхи здійснення формувального оцінювання в початковій школі:

1. Педагогічне спостереження за діяльністю учнів.

2. Аналіз учнівських портфоліо, навчальних досягнень, результатів діагностичних робіт школярів.

3. Взаємооцінювання та самооцінювання результатів діяльності здобувачів освіти.

4. Оцінювання особистісного розвитку та соціалізації учнів батьками.

5. Упровадження прийомів зворотного зв'язку щодо сприймання, розуміння та засвоєння навчального матеріалу [6].

Для з'ясування ролі та місця контрольно-оцінювальної діяльності школярів в умовах Нової української школи в КЗВО «Одеська академія неперервної освіти Одеської обласної ради» проведено відповідне дослідження. У дослідженні взяли участь 87 учителів початкової школи Одеської області.

На питання щодо нормативно-правової бази, яку педагоги використовують у оцінюванні навчальних досягнень школярів, було названо «Методичні рекомендації щодо оцінювання навчальних досягнень учнів першого класу», «Методичні рекомендації щодо оцінювання навчальних досягнень учнів другого класу», «Методичні рекомендації щодо оцінювання навчальних досягнень учнів третього класу», «Методичні рекомендації щодо оцінювання навчальних досягнень учнів четвертого класу», «Методичні рекомендації щодо викладання навчальних предметів у закладах загальної середньої освіти у 2020/2021 навчальному році» тощо.

На питання «Чи готові ви до змін у своїй роботі у зв'язку з впровадженням нових підходів до оцінювання?» 74\% відчувають готовність до змін у роботі у зв'язку із впровадженням нових підходів до оцінювання, $14 \%$ - частково готові, а $12 \%$ - не готові до змін у своїй роботі.

Щодо форм оцінювання навчальних досягнень молодших школярів, то учителі (89\%) зазначили: формувальне, вербальне, діагностичне, підсумкове; усне та письмове; поточне, періодичне, тематичне, семестрове, річне; індивідуальне, групове, парне, фронтальне; описове, підсумкове тощо. Інколи вчителі початкової школи добавляли оцінні судження, двосторонній зв'язок, рефлексію, спостереження, учительські записи, само- та взаємооцінювання.

Щодо технік формувального оцінювання, які вчителі використовують у своїй діяльності, то було виокремлено: «лінійку успіху», резюме в одному реченні, «сигнальні картки», мініогляд, шкалу, рефлексивний екран, оціночні листки, «сходинки успіху», світлофор, рефлексію тощо. Такі відповіді свідчать про обізнаність учителів 3 формами та техніками формувального оцінювання в Новій українській школі.

На питання «Назвіть цифрові інструменти оцінювання навчальних досягнень учнів початкової школи» педагоги зауважили: сервіси Plickers, Kahoot, Triventy, сервіси для створення тестувань, хмари знань, хмари слів, Google сервіси, сервіси для ведення документації, віртуальні дошки тощо.

На питання «Які інновації з контрольно-оцінювальної діяльності школярів ви впроваджуєте?» педагоги відповіли таким чином: щоденник спостереження; позитивний зворотний зв'язок; оцінні судження; картки самооцінювання поведінки; види та форми рефлексії; сервіси для створення карти знань; картки групового оцінювання; лінійка самооцінювання; різні види online-pecypсів; техніки і методи формувального оцінювання; види рефлексії; технологія портфоліо тощо.

Щодо питання «3 якими поняттями у контексті оцінювання ви ознайомились вперше?» було зазначено: «компетентнісний тест», «індивідуальна картка самооцінювання», «тижневий звіт», «парадигма», «картка самооцінки в адаптаційний період», «щоденник спостереження», «метод «Чарівна лінійка», «стратегії оцінювання», «алгоритм роботи вчителя 3 формувального оцінювання», «прогностичне оцінювання», «діагностична робота» тощо. 
Щодо запитів та потреб учителів у здійсненні контрольно-оцінювальної діяльності, то більшість $(79 \%)$ потребують набуття професійних компетентностей в оцінюванні школярів, додаткового роз'яснення аспектів та технік формувального оцінювання, допомоги в опрацюванні та роз'ясненні особливостей оформлення та ведення звітної документації контрольно-оцінювальної діяльності учнів Нової української школи тощо.

Щодо напрямів самовдосконалення у контексті оцінювання педагогами виокремлено: поповнення власної скарбнички методами, прийомами та формами формувального оцінювання; оволодіння техніками та цифровими інструментами здійснення оцінювання; оволодіння методичними аспектами проведення оцінювання; роз'яснювальна робота з батьками щодо оцінювання навчальних досягнень учнів; систематична участь у семінарах та вебінарах щодо ролі оцінювання у формуванні особистості школяра тощо.

Констатуємо, загалом учителі орієнтуються в нормативно-правовому забезпеченні контрольно-оцінювальної діяльності школярів, оперують основними поняттями, застосовують інновації, впроваджують цифрові інструменти здійснення формувального оцінювання, однак деякі аспекти ще потребують додаткового роз'яснення та уточнення.
Висновки. Отже, контрольно-оцінювальна діяльність учнів в умовах Нової української школи набуває нового значення. Повністю зміщено акценти 3 вимірювання обсягу засвоєних знань та швидкості їх відтворення до досягнення школярами певного рівня компетентностей відповідно до окреслених вимог; від констатування того, що в учня не вдалося та не вийшло до визначення власних результатів та здобутків. Отже, варто контролювати та оцінювати не скільки результат, стільки процес набуття знань, формування умінь та розвиток компетентностей дитини, при цьому зважаючи на їхні індивідуальні особливості та рівень пізнавальної самостійності. Важливим $\epsilon$ розуміння учнем справедливості та об'єктивності оцінювання, інакше поривання та наміри педагога будуть мати зовсім протилежний результат. Потрібно відповідально та правдиво ставитися до оцінювання, формулювати правильні оцінні судження, не допускати приниження людської гідності, прав та свобод дітей, по-різному заохочувати учнів до самоконтролю, само- та взаємооцінювання.

Перспективним напрямом у здійсненні подальших досліджень вважаємо вивчення та обгрунтування шляхів здійснення формувального оцінювання навчальних досягнень учнів Нової української школи.

\section{ЛIТЕРАТУРА}

1. Вілмут Дж. Оцінювання для навчання : навчальний посібник / За ред. I.Є. Булах, М.Р. Мруга. Київ : Майстер-клас, 2007. 170 с.

2. Кабан Л.В. Формувальне оцінювання навчальних досягнень учнів у Новій українській школі. Народна освіта. Київ, 2017. Вип. 1. С. 88-95. URL: http://nbuv.gov.ua/UJRN/NarOsv_2017_1_15/.

3. Коберник I. Оцінювання в Новій українській школі: ресурс для розвитку замість вироку. $2 \overline{0} 1 \overline{8}$. URL: https://nus.org.ua/view/otsinyuvannya-v-novij-ukrayinskij-shkoli-resurs-dlya-rozvytku-zamist-vyroku/.

4. Локшина О. Інновації в оцінюванні навчальних досягнень учнів у шкільній освіті країн Європейського Союзу. Порівняльно-педагогічні студії. Умань, 2009. № 2. С. 107-113.

5. Методичні рекомендації щодо оцінювання навчальних досягнень учнів першого класу : Додаток до наказу МОН України від 20.08.2018. № 924. URL: https://mon.gov.ua/storage/app/media/zagalna\%20 serednya/924.pdf.

6. Методичні рекомендації щодо оцінювання навчальних досягнень учнів другого класу : Наказ Міністерства освіти і науки України від 27.08.2019. № 1154. URL: https://mon.gov.ua/storage/app/media/ zagalna\%20serednya/novaukrschool/08/29/2-klas-nush.pdf.

7. Морзе Н.В., Барна О.В., Вембер В.П. Формувальне оцінювання: від теорії до практики. Інформатика та інформачійні технологї̈ в навчальних закладах. Волинь, 2013. № 6. С. 45-57.

8. Нова українська школа : порадник для вчителя / за заг. ред. Н.М. Бібік. Київ : Літера ЛТД, 2018. $160 \mathrm{c}$.

9. Покрова С. Досвід застосування формувального оцінювання навчальних досягнень молодших школярів. Wschodnioeuropejskie Czasopismo Naukowe. East European Scientific Journal. Варшава, 2019. № 12 (52). C. 6-10.

10. Пометун О., Ремех Т. Оцінювання учнів з громадянської освіти в контексті компетентнісного підходу. Український педагогічний журнал. Київ, 2019. № 1. С. 86-97.

11. Ротфорт Д.В., Гезей О.М. Нова українська школа: теорія і практика формувального оцінювання у 3-4 класах закладів загальної середньої освіти : навчально-методичний посібник / за заг. ред. Л.Д. Покроєвої. Харків : Вид-во «Ранок», 2020. 144 с.

12. Хурінайнен-Косунен А., Палмквіст Р. Матеріали тренінгу для тренерів НУШ «Педагогіка початкової школи: фінський досвід». Модуль 3. «Практика та інструменти оцінювання в школі». 16-18 жовтня 2019 р. м. Київ. 


\section{REFERENCES}

1. Vilmut, J. (2007). Otsiniuvannia dlia navchannia [Assessment for learning]. I.Ye. Bulakh, M.R. Mruha (Ed.). Kyiv: Maister-klas [in Ukrainian].

2. Kaban, L.V. (2017). Formuvalne otsiniuvannia navchalnykh dosiahnen uchniv u Novii ukrainskii shkoli [Formative assessment of pupils' academic achievements in New Ukrainian school]. Public education. Vol. 1. P. 88-95. Retrieved from: http://nbuv.gov.ua/UJRN/NarOsv_2017_1_15/ [in Ukrainian].

3. Kobernyk, I. (2018). Otsiniuvannia v Novii ukrainskii shkoli: resurs dlia rozvytku zamist vyroku [Assessment in the New Ukrainian School: A Resource for Development Instead of a Sentence]. Retrieved from: https://nus.org.ua/view/otsinyuvannya-v-novij-ukrayinskij-shkoli-resurs-dlya-rozvytku-zamist-vyroku/ [in Ukrainian].

4. Lokshyna, O. (2009). Innovatsii v otsiniuvanni navchalnykh dosiahnen uchniv u shkilnii osviti krain Yevropeiskoho Soiuzu [Innovations in the assessment of pupils' academic achievements in school education in the European Union]. Comparative and pedagogical studies. Vol. 2. P. 107-113 [in Ukrainian].

5. Metodychni rekomendatsii shchodo otsiniuvannia navchalnykh dosiahnen uchniv pershoho klasu (20.08.2018. No. 924.) [Methodical recommendations for assessing the academic achievements of the first grade students]. Retrieved from: https://mon.gov.ua/storage/app/media/zagalna\%20serednya/924.pdf [in Ukrainian].

6. Metodychni rekomendatsii shchodo otsiniuvannia navchalnykh dosiahnen uchniv druhoho klasu (27.08.2019. No. 1154) [Methodical recommendations for assessing the academic achievements of the second grade students]. Retrieved from: https://mon.gov.ua/storage/app/media/zagalna\%20serednya/ novaukrschool/08/29/2-klas-nush.pdf [in Ukrainian].

7. Morze, N.V., Barna, O.V., Vember, V.P. (2013). Formuvalne otsiniuvannia: vid teorii do praktyky [Formative assessment: from theory to practice]. Informatics and information technologies in educational institutions. Vol. 6. P. 45-57 [in Ukrainian].

8. Bibik, N.M. (Ed.) (2018). Nova ukrainska shkola: poradnyk dlia vchytelia [New Ukrainian school: a guide for teachers]. Kyiv: Litera LTD [in Ukrainian].

9. Pokrova, S. (2019). Dosvid zastosuvannia formuvalnoho otsiniuvannia navchalnykh dosiahnen molodshykh shkoliariv [Experience of application of formative assessment of educational achievements of junior schoolchildren]. Wschodnioeuropejskie Czasopismo Naukowe. East European Scientific Journal. Vol. 12 (52). P. 6-10 [in Ukrainian].

10. Pometun, O., Remekh, T. (2019). Otsiniuvannia uchniv z hromadianskoi osvity v konteksti kompetentnisnoho pidkhodu [Assessment of students in civic education in the context of the competency approach]. Ukrainian pedagogical journal. Vol. 1. P. 86-97 [in Ukrainian].

11. Rotfort, D.V., Hezei, O.M. (2020). Nova ukrainska shkola: teoriia i praktyka formuvalnoho otsiniuvannia u 3-4 klasakh zakladiv zahalnoi serednoi osvitu [New Ukrainian school: theory and practice of formative assessment in 3-4 grades of general secondary education]. L.D. Pokroieva (Ed.). Kharkiv: Vyd-vo "Ranok" [in Ukrainian].

12. Khurinainen-Kosunen, A., Palmkvist, R. (2019). Materialy treninhu dlia treneriv NUSh "Pedahohika pochatkovoi shkoly: finskyi dosvid" [Training materials for NUS trainers "Primary school pedagogy: Finnish experience"]. Module 3. "Practice and tools of assessment in school". Kyiv [in Ukrainian]. 